\title{
SEROPREVALENCE OF RUBELLA ANTIBODIES IN PREGNANT WOMEN
}

\author{
Jubaida $\mathrm{N}^{1}$, Mondal $\mathrm{MEA}^{2}$, Kawsar $\mathrm{NM}^{3}$
}

\begin{abstract}
Introduction: Clinical or subclinical infection of rubella of pregnant mother gives rise to a handicap baby to the society. Some time affected baby born apparently normal, but subsequently expresses disability.

Objective: This study was carried out to see the seroprevalence of rubella antibodies in pregnant women.
\end{abstract}

Method: Single blood sample was taken from 134 pregnant women, 66 from 1st trimester, 36 from 2 nd trimester and 32 from 3rd trimester. Blood samples were collected from different Out Patient Departments (OPD) of Combined Military Hospital (CMH) and Armed Forces Institute of Pathology (AFIP) over a period of six months. All the sera were examined by enzyme-linked immunosorbant assay (ELISA) for rubella specific Immunoglobulin $M$ (IgM) and Immunoglobulin G (IgG).

Result: The over all prevalence of seropositivity for IgG was $84.33 \%$ indicating that they were immune for rubella infection and the rest $15.67 \%$ were susceptible for rubella infection. The seropositivity for IgM antibody was $\mathbf{0 . 7 5 \%}$, which was a single case found in 22 year old pregnant women in 3rd trimester and was 2nd gravida. The study demonstrated that $85.71 \%$ of the pregnant women between the ages of 15 to 20 years had rubella IgG, peaking at $87.80 \%$ in the age group $26-30$ years and the seropositivity lower to $66.67 \%$ in the age group 31- 35 years.

Analysis of rubella specific IgG antibody among the different socio-economic group population in the present study, showed that seropositivity rate was much higher in lower $(91.67 \%)$ socio-economic status group, $89.02 \%$ in middle status group and the difference was lower in upper $(\mathbf{7 2 . 5 0 \%})$ socioeconomic status group and the difference was statistically significant $(\mathbf{p}<0.05)$. Higher $(86.84 \%)$ incidence of seropositivity for IgG antibody was observed in women presenting with adverse pregnancy out comes than that the normal pregnancy $\mathbf{( 8 0 . 6 5 \% )}$ out comes group.

Conclusion: The present study revealed that the substantial percentage of pregnant women were susceptible for rubella infection. The findings of this study will help to formulate a guideline for taking nation wide vaccination program.

Key words: Rubella antibody, seroprevalence, pregnant women

\section{Introduction}

A physically or mentally handicapped child becomes burden for the family as well for the society. Some infections which the mother contacts during pregnancy may cause handicaps like infections caused by Rubella virus, Cytomegalovirus (CMV), Toxoplasma gondii and syphilis ${ }^{1}$. These infections are usually subclinical and the affected children may born apparently well, but subsequently develop the evidence of mental retardation and other disabilities ${ }^{2}$.

Mental retardation is observed from 0.2 to $0.5 \%$ in the population of USA and $0.3 \%$ in UK. It is estimated that $85 \%$ of the world's disabled children live in less developed countries ${ }^{3}$. The incidence of mental retardation $(\mathrm{IQ}<50)$ in Pakistan is $4.2 \%{ }^{4}$. In Bangladesh, nearly $7 \%$ children have developmental disabilities ${ }^{5}$. Rubella virus is most consistent in its harmful effects on foetus. The virus can be transmitted to the foetus through the placenta and is capable of causing serious congenital defects (congenital rubella syndrome- CRS), abortion and still birth ${ }^{6}$. The risk of foetal infection is about $90 \%$ during first trimester, when the majority of these infants suffer from congenital defects ${ }^{7}$. Total or partial blindness (78\%), sensorineural hearing loss $(66 \%)$, psychomotor delay $(62 \%)$, mental retardation $(42 \%)$ and heart disease $(58 \%)$ are commonly found in infants with congenital rubella ${ }^{8}$. Deafness is the most common sequelae and was found in two thirds of all children with congenital rubella infection ${ }^{9}$. There is a $2 \%$ mortality rate among the congenitally infected infants who were symptomatic at birth $^{10}$. Diagnosis of rubella by clinical evidence may not be reliable and does not give a complete picture of the situation because nearly one half of individuals infected with this virus are asymptomatic ${ }^{6}$. Laboratory diagnosis includes isolation of virus and detection of rubella specific antibodies in the serum ${ }^{11}$.

1. Lt Col Nishat Jubaida MBBS, DCP, FCPS Classified Specialist in Pathology, Boarder Guard Bangladesh (BGB) Hospital, Dhaka; 2.Brig Gen Md Eunus Ali Mondal MBBS, FCPS, Dran, Faculty of Medical Studies, BUP; 3. Lt Col Narjis Maliha Kawsar MBBS, DCP, FCPS Classified Specialist in Pathology, CMH Saidpur. 
In Bangladesh, a study was carried out in Dhaka in 19941995 on 120 disabled children. Amongst them 25 $(20.83 \%)$ were seropositive for rubella specific antibody. It was found that $40 \%$ mother of the seropositive children had clinical history suggestive of rubella in the 1 st trimester and $12 \%$ in the 2 nd trimester of the pregnancy $^{12}$. Another study in Bangladesh on 50 congenitally handicapped children and their mothers found that prevalence of rubella antibody was $48 \%$ in children and $62 \%$ in the mothers of those children ${ }^{13}$. The risks of developing congenital defects are inversely related to gestational age. If the maternal infection occurs before 9 weeks of gestation the risk of foetal manifestations is $85 \%$, if infection occurs between 9 to 12 weeks then the risk of foetal manifestations is $52 \%$ and foetal manifestations is rare if maternal infection occurs after 16 weeks of gestation ${ }^{14}$. These findings indicate that rubella infection in pregnancy is an alarming health hazard.

Prevention of morbidity and mortality from rubella infection depends on prevention of the infection in childbearing women and early recognition of maternal infection ${ }^{11}$. The present study was carried out on the seroprevalence of rubella in pregnant women to see their immune status and their vulnerability to rubella infection.

\section{Materials and Methods}

Study was carried out at the Immunology Department of the Armed Forces Institute of Pathology (AFIP), Dhaka Cantonment covering period from October 2003 to March 2004. A total of 134 pregnant women were included in the prospective study in three groups. Sixty six cases from the first trimester, 36 cases from the second trimester and 32 cases from the third trimester were taken from different family out patient departments of Combined Military Hospital (CMH), Dhaka and out patients from AFIP irrespective of age and parity.

The economic conditions of the study subjects were ascertained by interviewing the pregnant women regarding their monthly income from all possible sources. The study populations were then categorized into different groups ${ }^{15}$ :

m Low-income group : Having monthly income of less than Taka 3000

m Middle income group : Having monthly income between Taka 3001 and 20,000

$\mathrm{m}$ Upper income group : Having monthly income more than Taka 20,000

About 2-3 $\mathrm{ml}$ of single blood sample was collected aseptically by venipuncture in a sterile, dry test tube from each pregnant woman. Sera samples were tested for detection of IgM and IgG antibody specific for Rubella virus by enzyme-linked immunosorbant assay (ELISA).
The tests were performed with commercially available kits and manufacturer's instructions were strictly adhered to in the performance and interpretation of the tests.

\section{Results}

Out of 134 cases $0.75 \%$ and $84.33 \%$ were seropositive for rubella specific IgM and IgG antibodies respectively. Relationship between duration of pregnancy and rubella specific IgG and IgM antibodies is shown in table-I.The distribution of age in different trimester is shown in (Table-II).

Table-I: Relationship between duration of pregnancy and Rubella specific IgM and IgG antibodies $(n=134)$

\begin{tabular}{|c|c|c|}
\hline \multirow{2}{*}{ Gestational age } & \multicolumn{2}{|c|}{$\begin{array}{c}\text { Seropositive Cases } \\
\text { Number (\%) }\end{array}$} \\
\cline { 2 - 3 } & IgM & IgG \\
\hline 1st Trimester $(\mathrm{n}=66)$ & - & $51(77.27)$ \\
\hline 2nd Trimester $(\mathrm{n}=36)$ & - & $33(91.67)$ \\
\hline 3rd Trimester $(\mathrm{n}=32)$ & $1(3.12)$ & $29(90.63)$ \\
\hline
\end{tabular}

Table-II: Distribution of subjects according to age group and different trimester $(\mathrm{n}=134)$

\begin{tabular}{|l|c|c|c|c|}
\hline $\begin{array}{l}\text { Age } \\
\text { Group }\end{array}$ & $\begin{array}{c}\mathbf{1}^{\text {st }} \\
\text { Trimester }\end{array}$ & $\begin{array}{c}2^{\text {nd }} \\
\text { Trimester }\end{array}$ & $\begin{array}{c}3^{\text {rd }} \\
\text { Trimester }\end{array}$ & Total (\%) \\
\hline $15-20$ & 10 & 07 & 04 & $21(15.67)$ \\
\hline $21-25$ & 26 & 13 & 15 & $54(40.30)$ \\
\hline $26-30$ & 21 & 10 & 10 & $41(30.60)$ \\
\hline $31-35$ & 09 & 06 & 03 & $18(13.43)$ \\
\hline Total & 66 & 36 & 32 & 134 \\
\hline
\end{tabular}

The mean age was 25.29 years and range was 17 to 35 years. Highest seropositivity of $\operatorname{IgG}(87 \%)$ was found in age group 26-30 year as well as 21-25 years age group (Table-III).

Table -III: Relationship between Rubella specific IgG with maternal age group $(n=134)$

\begin{tabular}{|l|c|c|}
\hline Age group & Number & $\begin{array}{c}\text { IgG Antibody Positive } \\
\text { Number (\%) }\end{array}$ \\
\hline $15-20$ & 21 & $18(85.71)$ \\
\hline $21-25$ & 54 & $47(87.04)$ \\
\hline $26-30$ & 41 & $36(87.80)$ \\
\hline $31-35$ & 18 & $12(66.67)$ \\
\hline Total & 134 & $113(84.33)$ \\
\hline
\end{tabular}

Relationships between rubella specific IgM \& IgG antibodies with gravidity, socioeconomic condition and with previous obstetric performance are respectively shown in (tables IV, V and VI). High seroprevalence rate of $\operatorname{IgG}(91.67 \%)$ was found in lower socioeconomic group which is statistically significant $\left(x^{2}=6.9, \mathrm{p}<0.05\right)$. Seropositivity for IgM antibody was found only in one case, which belonged to middle socioeconomic group. Out of 134 cases, 34 cases were primigravida. Rest of the 100 cases, 62 cases had normal pregnancy out come. 
In adverse previous pregnancy out come group one seronegative case had 2 abortions and one seropositive case had one stillbirth.

Table-IV: Relationship between Rubella specific IgM \& $\mathrm{IgG}$ antibodies and gravida $(\mathrm{n}=134)$

\begin{tabular}{|l|c|c|c|}
\hline \multirow{2}{*}{ Parity } & \multirow{2}{*}{ Number } & \multicolumn{2}{|c|}{$\begin{array}{c}\text { Seropositive } \\
\text { Number (\%) }\end{array}$} \\
\cline { 3 - 4 } & & IgM & IgG \\
\hline Primi Gravida & 34 & - & $30(88.24)$ \\
\hline $2^{\text {nd }}$ Gravida & 56 & $01(1.79)$ & $50(89.29)$ \\
\hline $3^{\text {rd }}$ Gravida & 33 & - & $23(69.70)$ \\
\hline $4^{\text {th }}$ Gravida & 10 & - & $09(90.00)$ \\
\hline $5^{\text {th }}$ Gravida & 01 & - & $01(100.0)$ \\
\hline Total & 134 & $01(0.75)$ & $113(84.33)$ \\
\hline
\end{tabular}

Table-V: Seroprevalence of Rubella specific $\operatorname{IgM}$ and $\mathrm{IgG}$ in different socioeconomic groups $(\mathrm{n}=134)$

\begin{tabular}{|l|c|c|c|}
\hline \multirow{2}{*}{$\begin{array}{l}\text { Scioeconomic } \\
\text { Group }\end{array}$} & \multirow{2}{*}{ Number (\%) } & \multicolumn{2}{|c|}{ Seropositive (\%) } \\
\cline { 3 - 4 } & & IgM & IgG \\
\hline Upper & $40(29.85)$ & - & $29(72.50)$ \\
\hline Middle & $82(61.2)$ & $01(1.22)$ & $73(89.02)$ \\
\hline lower & $12(8.95)$ & - & $11(91.67)$ \\
\hline Total & $134(100)$ & $01(0.75)$ & $113(84.33)$ \\
\hline
\end{tabular}

Table-VI: Relationship between Rubella specific antibody with previous obstetric performance $(n=100)$

\begin{tabular}{|l|c|c|}
\hline $\begin{array}{l}\text { Obstetric } \\
\text { Performance }\end{array}$ & Number (\%) & $\begin{array}{c}\text { IgG Seropositive } \\
\text { Number (\%) }\end{array}$ \\
\hline $\begin{array}{l}\text { Normal pregnancy } \\
\text { outcome }\end{array}$ & $62(62)$ & $50(80.65)$ \\
\hline $\begin{array}{l}\text { Adverse pregnancy } \\
\text { outcome }\end{array}$ & $38(38)$ & $33(86.84)$ \\
\hline Total & 100 & $83(83.00)$ \\
\hline
\end{tabular}

All other adverse pregnancies, out come were spontaneous abortion in the 1 st trimester of gestation.

\section{Discussion}

In the present study, sera from 134 pregnant women were taken. Out of them 66 from 1st trimester, 36 from 2nd trimester and 32 from 3rd trimester were examined for rubella specific IgM and IgG antibodies by ELISA. An attempt was made to assess the seroprevalence rate of rubella specific antibodies in pregnant women on the basis of serodiagnosis.

The over all prevalence of seropositivity for IgG was $84.33 \%$, that means, they were immune for rubella infection and the rest $15.67 \%$ seronegative cases were susceptible for rubella infection. The prevalence of seropositivity for IgM was found in only one $(0.75 \%)$ case. In a similar study in Pakistan; the over all seropositivity for rubella specific IgG was observed in $94 \%$ cases $^{16}$. Another report from India showed the seroprevalence rate in pregnant women was $67.8 \%$, that is, a large group is susceptible for rubella infection ${ }^{17}$. In Malaysia, it was observed that the immunity of rubella in pregnant women was $92.3 \%{ }^{18}$. In Iran, seropositivity rate among women of childbearing age were $96.2 \%, 93 \%$ and $94.9 \%$ in different studies ${ }^{19}$. Similar study was carried out in Haiti, and it was observed that the $95.2 \%$ cases were seropositive for rubella specific IgG and 4.8\% pregnant women were susceptible for rubella ${ }^{20}$. In Bangladesh, a study was carried out among antenatal population attending a tertiary level hospital in Dhaka City. In that study it was observed that $85.9 \%$ were seropositive and $14.1 \%$ were seronegative for rubella specific IgG antibody ${ }^{21}$. These results correlate with the present study.

In 1995-96, World Health Organization (WHO) conducted a study to assess the rate of CRS per 1000 live births in developing countries. These ranged from 0.62.2 and were similar to those reported from industrialized countries during the pre vaccine era. The same study also assessed seroprevalence among the women of child bearing age of 45 developing countries and $10-25 \%$ of the women tested were seronegative ${ }^{22}$. These findings point out the alarming fact that due to the failure to adopt an immunization policy, the susceptibility and rates of CRS have remained unchanged in developing countries even 30 years after the discovery of the rubella vaccine.

There is considerable variation in the prevalence of rubella antibodies among women of childbearing age. European women have relatively higher prevalence of rubella immunity $(93.2 \%)$ as compared to women of African (86.7\%) and Asian origin (78.4\%). In India the reported figures vary from $53 \%$ to $94.1 \%$. The reason for this difference in immunity is difficult to explain. However, factors such as net birth rate, population density, opportunities for entry of virus, level of herd immunity at the time of virus introduction and ethnicity of the population may be responsible for this variation ${ }^{17}$.

In the present study, the seropositivity for IgM antibody was $0.75 \%$, which was a single case found in 22 years old pregnant women in 3rd trimester and was 2nd gravida. In Pakistan 3\% of the study population were found seropositive for rubella specific IgM antibody in a study ${ }^{16}$. In India it was seen in one report that the seropositivity of IgM antibody was $6.5 \% 23$. Present study demonstrated that $85.71 \%$ of the pregnant women between the ages of 15 to 20 years had rubella $\mathrm{IgG}$, peaking at $87.80 \%$ in the age group $26-30$ years. The seropositivity decreased to $66.67 \%$ in the age group 31 35 years. This result correlates with one study carried out in Bangladesh where $80 \%$ of the pregnant women were between ages of 15-20 year's group that had rubella IgG antibody. Seroprevalence increased with age, peaking at 
$87 \%$ in the age group of $26-30$ years $^{21}$. In India, one study showed that the seropositivity amongst the age group $16-25$ years was $69.2 \%, 77.2 \%$ in $26-35$ years and $59.3 \%$ in $36-45$ years $^{17}$. Therefore the age specific seroprevalence of the present study is similar to previous study in Bangladesh and also similar to the neighbouring country.

In the present study, $70.90 \%$ of pregnancies occurred in 21-30 year group, indicating a $11.2 \%$ risk of rubella infection during their pregnancies. It is similar to the study of Ashrafunnesa et al. Author observed that the $70 \%$ of pregnancies occurred at 21-30 year group ${ }^{21}$. Seroprevalence of IgG antibody from $43 \%$ amongst primigravida to $59 \%$ and $78 \%$ in multiparous grand multiparous women respectively were observed ${ }^{24}$.

Analysis of rubella specific IgG antibody among the different socioeconomic group population in the present study showed that seropositivity rate was much higher in lower $(91.67 \%)$ socioeconomic status group and lower in upper $(72.50 \%)$ socioeconomic status group which is statistically significant $(\mathrm{p}<0.05)$. Crowded living conditions in lower class population might increase the chance of exposure to rubella infection. In India a study showed the similar type of incidence in the different socioeconomic status group, rubella specific IgG antibody positive in $55.9 \%$ in upper group, $67.3 \%$ and $71.8 \%$ in middle and lower socioeconomic status group respectively ${ }^{17}$. In another study in Bangladesh, population from lower socioeconomic class showed higher prevalence of rubella antibody $(69.2 \%)$ than the observed upper class $(55.6 \%)^{25}$.

In the present study, the higher $(86.84 \%)$ incidence of seropositivity for IgG antibody was observed in women presenting with adverse pregnancy out comes than that of the normal pregnancy $(80.65 \%)$ out comes group, suggested that rubella could be a cause of repeated pregnancy wastage in those women. Similar evidence was seen in Punjab, India that higher (73.2\%) incidence was seen in the adverse pregnancy out come group than the normal $(69.5 \%)$ obstetric out come group ${ }^{17}$.

\section{Conclusion}

Rubella in pregnancy especially during the first 12 weeks of pregnancy may lead to congenital malformation in the form of deafness, cataract, congenital heart disease, mental retardation and even foetal death. The out come of congenital rubella is tragic consequence for both the infant and the parents. Rubella is a preventable viral disease after introducing successful vaccination. In large number of developing countries a proper and adequate vaccination policy was not adopted at national level. This is probably due to non-focusing on rubella-related problems or numerous other healthrelated issues keeping this important morbidity-related issue out of sight. Also governments of these countries are not probably motivated to carry the huge economic expenditure required for rubella immunization program. This small preliminary study indicates that like many other countries rubella is an endemic condition in Bangladesh and the requirement of detailed study for identification and its influence on perinatal morbidity and mortality. More detailed epidemiological studies for a basis of national immunization program is also needed.

Providing a recommended vaccination program, early detection of maternal rubella infection, can easily be prevented congenital rubella by screening. Thus we can eradicate rubella like small pox from our global village.

\section{Refernces}

1. Bale JF, Murph JR. Congenital infections and the nervous system. Pediatr Clin N Am 1992; 39:669-690.

2. Remington JS, Klein JO, editors. Infectious Diseases of the Fetus and Newborn Infant, 3rd ed. Philadelphia: W.B. Saunders Company; 1990: 87-195.

3. Helander EAS. Prejudice and dignity: An introduction of community based rehabilitation. Intern J Rehab Res 1993; 15:115-127.

4. Yaqoob M, Bashir A, Tarreen K,et al. Severe mental retardation in 2 to 24 month-old children in Lahore, Pakistan: A prospective cohort study. Acta Paediatr 1995; 84(3): 167-172.

5. Durkin MS, Zaman SS, Thorbun M, et al. Screening for childhood disability in less developed countries: Rationale and study design. Intern J Mental Health 1991; 20: 47-60.

6. Ezike E, Ang JY, Asmar B. Rubella. In: Krilov LR, Windle LM, Barton LL, Tolan RW, Steele R, editors. e-Medicine; 2003 May 10.

7. Ueda K, Nishida Y, Oshima K. Congenital rubella syddrome: correlation of gestational age at time of maternal rubella with type of defect. J Pediatr 1989; 94: 763-766.

8. Givens K, Lee DA, Jones T, Ilstrup DM. Congenital rubella syndrome: Ophthalmic mainfestations and associated systemic disorders. Br J Ophthalmol 1993; 77:358-363.

9. Cooper LZ, Ziring PR, Ockerse AB, Fedrea BA, Keity B, Krugman S. Rubella: Clinical manifestations and management. Am J Dis Child 1989;118:18-29.

10. Katz SL. Rubella (German Measles). In: Joklik WK, Willett HP, Amos DB, Wilfert CM, editors. Zinsser Microbiology. 20th ed.California: Appleton \& Lange ; 1992. p. 1016-1018.

11. Banatvala JE, Best JM. Rubella. In: Parker MT, Collier LH, and editors. Topley and Wilson's Principles of Bacteriology, Virology and Immunology, volume 4. 8th ed. Philadelphia: B.C. Decker, Inc; 1988. p.501-532.

12. Zarin S. Seroepidemiological studies in Congenital neurological and other disabled cases due to some probable micobial causes (Thesis). Dhaka: IPGMR; 1996. p.101.

13. Islam S, Hussain MZ, Habib MA, Ahmed Z. Prevalence of rubella antibody among the handicapped children and their mother. Bangladesh Armed Forces Medical Journal 1997 June; 21(1): 41-45.

14. Ely JW, Yankowitz J, Bowdler NC. Evaluation of Pregnant Women Exposed to Respiratory Viruses. American Family Physician 2000May; 15: 65-74.

15. Islam N. The poor's access to urban land for housing. Urban land Management in Bangladesh. Government of Bangladesh: Ministry of Land; 1992. p. 131-140.

16. Kharal SA, Khan MA. Prevalence of rubella seropositivity at successive stages of pregnancy. Pak Armed Forces Med J 1997; 47(1):11-14.

17. N Singla, N Jindal, A Aggarwal. The seroepidemiology of rubella in Amritsar (Punjab). Indian Journal of Medical Microbiology, 2004; 22(1): 61-63.

18. Sekawi Z, Isahak I, Najib MM, Yassin AJ. Rubella immunity status in pregnant women Kuala Lumpur, Malaysia. Medical Journal of Malaysia 2000; 55: 299-302. 
19. Doroudchi M, Samsami, Dehaghani, Emad K, Ghaderi AA. Seroepidemiological survey of rubella immunity among three populations in Shiraz, Islamic Republic of Iran. Eastern Mediterranean Health Journal 2001; 7 (1/2): 128-138.

20. Désinor OY, Renette JP, Anselme, Fernando L, Calerbe St L, Jean EBA. Seroprevalence of antibodies against rubella virus in pregnant women in Haiti. Rev Panam Salud Publica/ Pan Am J Public Health 2004; 5(3): 147-149.

21. Ashrafunnessa, Khatun $\mathrm{S}$, Islam $\mathrm{MN}, \mathrm{S}$ Chowdhury. Seroprevalence of rubella antibodies among antenatal population attending a tertiary level hospital in Dhaka city. Bangladesh Med Res Counc Bull 2000; 26(3): 75-81.

22. Cutts FT, Robertson SE, Diaz-Ortega JL, Samuel R. Control of rubella and congenital rubella syndrom (CRS) in developingcountries, part 1: burden of disease from CRS.Department of Vaccines And Biologicals. Geneva: World Health Organization; 2000. p. 5.

23. Yasodhara P, Ramalakshmi BA, Naidu AN, Rahman L. Prevalence of specific IgM due to Toxoplasma, Rubella, CMV and C.trachomatis infections during pregnancy. Indian Journal of Medical Microbiology $2001 ; 19(2): 52-56$

24. Bukbuk DN, EI Nafaty AU, Obed JY. Prevalence of rubellaspecific IgG antibody in non-immunized pregnant women in Maiduguri, Northeastern Nigeria. Central European Journal for Public Health 2002; 1-2 : 21-23.

25. Nahar N. The seroepidemiology of rubella in Dhaka, Bangladesh (Thesis). Dhaka: IPGMR; 1984. p. 66-75. 